\title{
Effects of Wetland Creation on Breeding Season Bird Use in Boreal Eastern Ontario
}

\author{
DAVID A. Locky ${ }^{1,4}$, J. Chris DAVIES ${ }^{2,3}$, and BARry G. WARneR ${ }^{2}$ \\ ${ }^{1}$ Biological Sciences Department, University of Alberta, Edmonton, Alberta T6G 2E9 Canada \\ ${ }^{2}$ Wetlands Research Centre and Department of Biology, University of Waterloo, Waterloo, Ontario N2L 3G1 Canada \\ ${ }^{3}$ Wildlife and Natural Heritage Section Ontario Ministry of Natural Resources, Peterborough, Ontario K9J 8M5 Canada \\ ${ }^{4}$ Present address: $1121264^{\text {th }}$ Street, Edmonton, Alberta T5W 4H3 Canada
}

Locky, David A., J. Chris Davies, and Barry G. Warner. 2005. Effects of Wetland Creation on Breeding Season Bird Use in Boreal Eastern Ontario. Canadian Field-Naturalist 119(1): 64-75.

Wetland construction has been an effective means of mitigating wetland habitat losses due to agricultural and other activities. However, the type, variety, and age of the habitats created are often critical components in the success of the wetland when the aim is to enhance the bird community. Hilliardton Marsh was constructed as a series of cells between 1993 and 1997 in boreal eastern Ontario to provide waterfowl habitat. We determined habitat change and monitored breeding-season bird use before construction and one year after the last cell was constructed. Wetland construction resulted in dramatic changes to the vegetation and bird communities. The area was transformed into a variety of wetland habitats, but primarily marsh, one of the rarest wetland types in boreal Ontario. Survey stations with moderate habitat change exhibited the greatest change in bird species richness. Total species richness increased 55\% from 56 to 87 species, with obligate wetland birds increasing from 3 to 26 species. Rare birds increased from 11 to 27 species, with most as obligate or facultative wetland birds, but also Peregrine Falcon (Falco peregrinus). Bird abundance, as measured by the number of stations where a species was observed, increased significantly for obligate wetland birds. There were no significant losses of species from any bird group, as adjacent upland habitat was preserved. This short-term study has shown that construction of new wetland habitat in boreal eastern Ontario, especially marsh, can significantly increase the numbers of breeding-season birds, including rare species. However, longterm monitoring is required to ensure sustained success of wetland construction projects for birds.

Key Words: boreal, breeding birds, constructed wetland, marsh, rare birds, upland birds, wetland birds, Ontario.

Constructing wetlands to offset lost wetlands and maintain wildlife habitat has been widespread and relatively successful in North America (Whitman 1976; Leschisin et al. 1992; Creighton et al. 1997). In Ontario, most of the initiatives have occurred in the south where wetland losses have been extensive. Wetland creation has been less common in the boreal part of the province where wetland losses have not been perceived to be important (Ritchie 1988). However, some boreal regions with glacio-lacustrine soils have seen significant numbers of wetlands lost to conversion for agriculture. One such area in northeastern Ontario is the Little Clay Belt (LCB), where many of the wetlands were drained for agriculture in the early 1900s (Davies et al. 1996).

Marshes were more extensive before settlement in the LCB and probably once supported a large population of waterfowl (Davies et al. 1996) (Figure 1). Marsh habitat is particularly critical for wetland birds and is one of the rarest wetland types in the boreal region (National Wetlands Working Group 1988). To address wetland losses in the LCB, Ducks Unlimited Canada (DU) and its partners have initiated a number of wetland creation projects, including Hilliardton Marsh in the Hilliardton Marsh Provincial Wildlife Area (HMPWA) (Figure 1). This constructed wetland is 209ha and one of the largest projects of its kind in Ontario. The wetland was created primarily for water- fowl brood-rearing habitat, and secondarily as staging habitat for waterfowl migrating to and from the Hudson Bay and James Bay lowlands (Davies et al. 1996). It was constructed between 1993 and 1997 and comprises five cells contained within $8.6 \mathrm{~km}$ of dikes. This site is managed by DU and water is drawn from the adjacent Blanche River.

In May and June 1993, a pre-construction inventory of the vegetation and bird communities at the Hilliardton Marsh site was commissioned by the Ontario Ministry of Natural Resources (OMNR) and DU. Results from the 1993 inventory indicated that the vegetation was predominantly upland and that only five species of wetland birds were observed on site (Davies et. al. 1996). Regionally rare birds were observed on the site and included Upland Sandpiper (for scientific names of birds see Table 3), Short-eared Owl, Eastern Meadowlark, and LeConte's Sparrow. Preliminary post-construction vegetation (Gilbert 1997) and bird surveys (Huizer and Henshaw 1997*) were completed in 1997 before the wetland was fully constructed. Results indicated that shallow water wetland and marsh habitat was created and that waterfowl and other wetland birds were attracted to the wetland (Huizer and Henshaw 1997*).

Few studies have examined the breeding bird communities in the Clay Belt of northern Ontario (Smith 1957; Erksine 1977), which is an important area from 


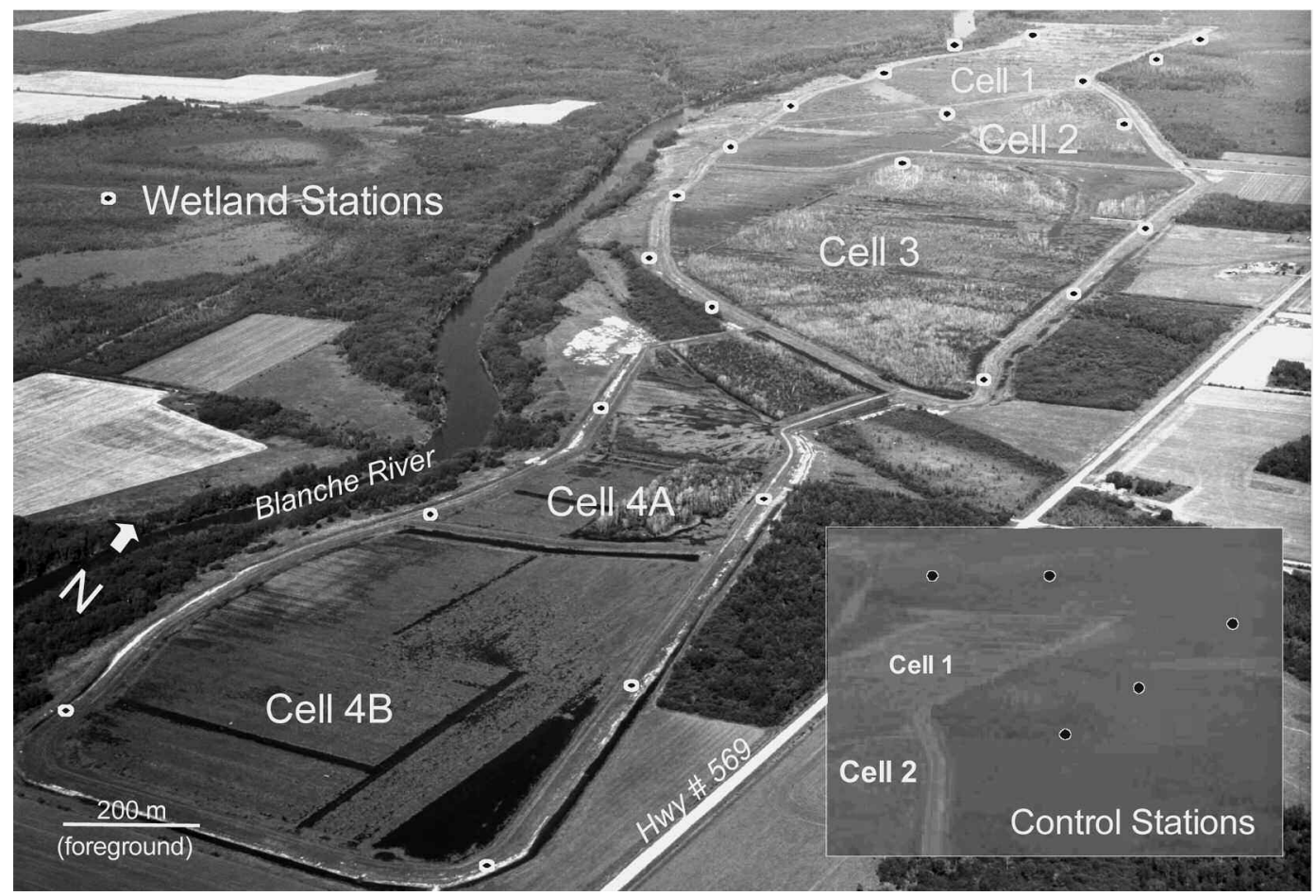

FIgURE 1. Hilliardton Marsh with 24 wetland bird survey stations on the dikes. Inset image shows five of six control stations outside and northeast of the wetland.

the perspective of marking the northern, eastern, and southern limits of the ranges of several bird species (Smith 1957). The purpose of this study was to determine the effects on the breeding-season bird community of complete construction of Hilliardton Marsh one year after completion and relate any changes to habitat transformation. The cells were aged from one to five years at the time of the survey. Our intent was not to provide a definitive assessment of wetland construction on breeding-season birds, but to illustrate the initial impacts of wetland construction on the bird community. Our specific objectives were to: (1) quantify habitat change in area flooded for the wetland and at the survey stations, (2) compare total and bird group species richness before and after wetland construction, (3) compare total and bird group species abundance before and after wetland construction, (4) determine changes in total and bird group rare species between years, and (5) examine the relationship between degree of habitat change and bird species richness between years.

We hypothesized that post-construction bird surveys would be dominated by wetland dependent species at stations with high habitat change, whereas survey stations with little or no habitat change would continue to be dominated by upland species. Stations with moderate habitat change would have the highest num- ber of species and abundances. We hypothesized that rare species would increase with the addition of wetland habitat and we expected no change in any variables at the control stations.

\section{Study Area}

Hilliardton Marsh Provincial Wildlife Area is $20 \mathrm{~km}$ north of New Liskeard, Ontario, Canada $\left(47^{\circ} 46^{\prime} \mathrm{N}\right.$; $79^{\circ} 42^{\prime} \mathrm{W} ; 190 \mathrm{~m}$ a.s.l.). The topography is relatively low relief and the glacio-lacustrine soils are clay-rich (Dredge and Cowan 1989), which together have contributed to poor drainage. The site lies in the greater Mid-Boreal Wetland Region where peatlands are the dominant wetland types (National Wetlands Working Group 1988) and approximately $4 \%$ is marsh (Riley 1988).

The LCB has cropland and pasture, second-growth mixed hardwood forest, and various types of natural wetlands that include mixed deciduous and coniferous swamp, fen, bog, and tall shrub swamp (Davies et al. 1996). Prior to construction, Hilliardton Marsh was agricultural land in various states of use and abandonment, with some second-growth Trembling Aspen (Populus tremuloides) forest. Approximately $20 \%$ of the area was shrub swamp dominated by Speckled Alder (Alnus incana ssp. rugosa) and willows (Salix spp.) (Davies et al.1996). 


\section{Methods}

\section{Habitat Survey}

Pre-construction habitat was delineated using a site plan (Ducks Unlimited 1986*) and post-construction habitat with 1998 aerial photographs (1:5000) and field reconnaissance. Description of the wetland classes followed the Canadian Wetland Classification System (National Wetlands Working Group 1997) and vegetation communities were defined by dominant vegetation forms following the Northern Ontario Wetland Evaluation (Ontario Ministry of Natural Resources 1994). The aereal coverage for each of the vegetation communities was calculated with a light planimeter for 1993 and 1998, and the extent of habitat change after flooding was determined. Habitat change within each of the $30200 \mathrm{~m}$ radius (12.6 ha) pointcount stations was also calculated. All of the wetland survey stations except two contained primarily upland habitat before flooding. Habitat change was therefore considered a general indicator of new wetland habitat. Stations were classified into three categories based on percent habitat change as follows: little or no change (0-19\%, 0-2.4 ha), moderate change (20-54\%, 2.5$6.8 \mathrm{ha})$, and high change (55-100\%, 6.9-12.56 ha).

\section{Bird Surveys}

Thirty $200 \mathrm{~m}$ radius avian point-count stations were established as repeatable survey points in 1993 (Huizer and Henshaw 1997) (Figure 1). Twenty-four of the wetland survey stations were placed $400 \mathrm{~m}$ apart (centre to centre) on the proposed wetland impoundment berms and were used to detect changes in the bird community related to wetland construction. Six control stations were located $400 \mathrm{~m}$ outside the dikes away from the flooding and were used to detect changes in species composition not associated with the flooding event (e.g., weather) [Inset image in Figure 1].

To provide a bird community data set comparable to that from 1993, we completed bird surveys at the same stations, during the same survey period, and for the same duration as the 1993 surveys. Different observers were used in 1993 and 1998, but the survey standardization minimized the probability of bird diversity changes between years being attributed to unequal sample effort (Elphick 1997). Stations were surveyed between sunrise and 10:00 am when there was good visibility, no precipitation, and little wind. Upon arrival at the station the surveyor faced north, waited five minutes, and then recorded all bird movements and auditory calls during a 10-minute interval (Canadian Wildlife Service 1997*). Pre-construction point-counts were conducted 22-24 May and 11-13 June 1993. Post-construction surveys were conducted 23-25 May and 18-20 June 1998. Birds were also noted outside of the survey circles in the study area during the survey period in both years to determine total species richness and composition.

\section{Bird Groups and Species Classification}

Bird species abundance (e.g., common, rare) and status (e.g., breeder, migrant) within the LCB region were determined according to a regional bird list (Temiskaming Field Naturalists 1994*) and the Northern Ontario Wetland Evaluation System (Ontario Ministry of Natural Resources 1994). Species were considered breeding on the site if there was a singing male on territory; a pair was observed, individuals were carrying food, or there was agitated behaviour (territoriality) (Huizer and Henshaw 1997*). Species recorded for counts during the May period were only considered breeding on the site if they were within their traditional breeding range, whereas species outside their known range were considered migrants. Species classified as migrants were removed from the breeding-bird data-sets in order to compare breeding-season birds within the LCB region. However, all species in the area during surveys were recorded by including birds observed outside of survey plots. The May and June bird surveys were combined to include both early and late breeding species (approximately 15 May - 15 July).

We classified bird species into five groups based on wetland/aquatic habitat dependency as determined and further modified by life history descriptions in Cadman et al. (1987) to better reflect boreal bird communities as follows:

I. Obligate Wetland (found greater than $99 \%$ in wetlands);

II. Facultative Wetland (57-99\%, generally found in or near wetlands);

III. Facultative (34-56\%, occurs frequently in wetlands, but wetlands are not essential);

IV. Facultative Upland (1-33\%, occasional or no use of wetlands); and

V. Upland (found greater than $99 \%$ in uplands).

The assignment of species groups or rankings to species and the results of associated statistical analyses have been a matter of discussion among experts (Simberloff and Dayan 1991). In particular, assignment of scarce species to categories, however defined, may be error-prone. However, our intent in using bird groups was to consider and monitor the bird community as a whole, with minor differences in individual rankings having little impact on the final analysis (c.f. Croonquist and Brooks 1991). Bird nomenclature in this study follows the American Ornithologist Union (AOU) $7^{\text {th }}$ Edition Checklist (AOU 1998), and supplements 42 (AOU 2000), 43 (AOU 2002), 44 (AOU 2003), and 45 (AOU 2004).

\section{Data Analysis}

We assumed that the point-count circles were large enough ( $200 \mathrm{~m}$ radius, $12.6 \mathrm{ha}$ in area) to include all or portions of territories for many breeding-season bird species and that the total coverage was representative of all habitat types measured at Hilliardton 
Marsh. The stations were $400 \mathrm{~m}$ apart, much farther than the minimum $250 \mathrm{~m}$ suggested by Freemark and Rogers (1995) and Ralph et al. (1995) to limit double counting. However, although station edges were touching and some independence in bird observations may be compromised, the temporal scale was relatively small and the change in species richness and presence at stations was of most interest to us in this study (see Bibby et al. 1993).

The calculation of bird abundance directly from point-count data is problematic (Bibby et al. 1993; Ralph et al. 1995). This is especially true with large survey circles as used in this survey, as the detectability of birds varies greatly among different habitats (Hutto et al. 1986), among bird species (Ralph et al. 1995), and distance from observers. Instead, we used the number of stations at which a species was observed each year as a proxy for species abundance (station/species/year). We assumed that if the actual abundance of a species increased, the probability that at least one bird is observed at a station would increase. Although there is potential to artificially inflate abundance due to the possibility of several stations equating the presence of only a single individual of a species, there is also a higher probability that a species will be present at a station and thus the expected number of stations at which that species is observed will also increase (Debinsky and Humphrey 1997).

Species counts were categorized by bird group and year, and by degree of habitat change and year. For statistical analysis, we assumed that bird observation stations and observations were independent of each other and utilized time-series statistical analyses (Hurlbert 1984). Wilcoxon's Rank Sign tests were used, as the untransformed and transformed data failed Levene's Test of Equality (SPSS Inc. 2002). This test was used to determine significant changes in mean numbers of total species and species/station for the wetland stations and control stations, changes between years for number of stations/species, a proxy for abundance, and changes between years of species/ station by low, moderate, and high habitat change. The McNemar Test for Significance of Changes (Conover 1980) was used to test for the significance of between-year $(1993,1998)$ changes in the number of stations at which a particular species was observed. All data analyses were completed using SPSS ver. 11.5.1 (SPSS Inc. 2002), except for the McNemar Test which was programmed using Microsoft Excel ${ }^{\circledR}$.

This study was somewhat constrained by the survey design used for the original 1993 study, and presented a number of limitations on the interpretation of our results. The Canadian Wildlife Service point count survey protocol was not specifically designed for open wetlands, for which the employment of broadcast bird calls to illicit responses from more secretive wetland birds is often used; wetland birds are often less evenly distributed than upland species, increasing the diffi- culty of sampling efforts (Bell et al. 1973). Because only two survey stations were not peripheral (i.e., did not include edge), diversity may be unrepresentatively high for wetland birds, and under sampled in other stations (see Erskine 1977). The use of six control stations may not be enough to accurately detect changes, as even if habitats were uniform, changes detected may not be truly representative for the area. With respect to the May count dates in low boreal habitats, some insectivorous birds may be under-represented due to not having returned in breeding numbers. Additionally, some of the rare species may be vagrants outside of their normal breeding range. Despite these limitations, we feel that the data contributes much needed information on not only breeding season birds in the Clay Belt where there have been few studies, but on the effects to birds of creating rare wetland habitat in a region with high wetland losses.

\section{Results \\ Habitat Change}

Habitat change was dramatic after the construction of Hilliardton Marsh. The agricultural fields that encompassed $71 \%$ of the site (145 ha) were largely submerged and all of the Trembling Aspen forest was flooded (13\% or 27 ha) (Table 1). The new wetland consisted of 54\% marsh (112 ha), wetland with shallow water and dominated by emergent aquatic graminiods, 29\% deciduous swamp (61 ha), wooded wetland dominated by either trees or shrubs, and 13\% shallow water wetland ( $27 \mathrm{ha}$ ), wetland with standing or flowing water less than $2 \mathrm{~m}$ in mid-summer, and dominated by floating aquatic macrophytes (National Wetlands Working Group 1997). Aerial photographs taken in 1998 indicated that a large proportion of the marsh exhibited hemi-marsh habitat (50:50 open water/ vegetation), which is attractive to aquatic birds (Weller 1994).

Habitat change at the survey stations was also significant, with four stations in the high change category (55-100\%), 20 stations in the moderate change category $(20-54 \%)$, and the six control stations in little/no change category (0-19\%). Fifteen of the 24 stations that were flooded as a result of wetland construction exhibited habitat change of at least $50 \%$.

\section{Total Bird Species Richness}

After wetland construction the total bird species richness on site increased 34\% from 72 species in 1993 to 109 species in 1998 . The 109 species represent $49 \%$ of the 222 birds that are known to occur on the LCB at any time as year-round residents, migrants, breeders, or winter residents (Temiskaming Field Naturalists 1994*) (Tables 2 and 3). At the HMPWA, 56 breeding species were observed, which reflects $36 \%$ of the 156 breeding species found in the in the LCB. This number increased to 87 species in 1998, or $56 \%$ of total observed breeding species in the LCB. 
TABLE 1. Summary of habitat type and area before and after construction of Hilliardton Marsh. Numbers in brackets are percent of total wetland.

\begin{tabular}{|c|c|c|c|c|c|}
\hline \multirow[b]{2}{*}{ Habitat Type } & \multicolumn{2}{|c|}{1993} & \multicolumn{2}{|c|}{1998} & \multirow{2}{*}{$\begin{array}{l}\% \text { Change } \\
1993-1998\end{array}$} \\
\hline & Area & (ha) & Area & (ha) & \\
\hline Early Successional Poplar/Alder Forest & 14.0 & (7) & 0.0 & $(0)$ & $(-7)$ \\
\hline Deciduous Woods & 9.0 & (4) & 0.0 & $(0)$ & $(-4)$ \\
\hline Early Successional White Birch/Poplar Fores & 4.0 & (2) & 0.0 & (0) & $(-2)$ \\
\hline Active Agricultural Field & 5.0 & (2) & 0.0 & $(0)$ & $(-2)$ \\
\hline Fallow/Hay Agricultural Field & 139.5 & $(67)$ & 9.0 & (4) & $(-63)$ \\
\hline Alder/Willow/Poplar Swamp & 37.5 & $(18)$ & 34.0 & (16) & $(-2)$ \\
\hline Shallow Water Wetland & 0.0 & $(0)$ & 27.0 & (13) & $(+13)$ \\
\hline Marsh & 0.0 & $(0)$ & 112.0 & (55) & $(+54)$ \\
\hline Dead Tree/Shrub Swamp & 0.0 & (0) & 27.0 & (13) & $(+13)$ \\
\hline Total & 209.0 & $(100)$ & 209.0 & $(100)$ & $(0)$ \\
\hline
\end{tabular}

\section{Survey Stations and Bird Groups}

Before construction of Hilliardton Marsh in 1993, most birds observed at survey stations were upland (30\%), facultative upland $(25 \%)$ and facultative species (25\%) (Tables 2 and 3). Only 14\% were facultative wetland species and 5\% were obligate wetland species. One year after wetland construction (1998), $30 \%$ of the survey station birds were obligate wetland species, with $22 \%$ each as facultative and upland species, $17 \%$ as facultative upland, and $9 \%$ as facultative wetland.

There were significant differences between years for overall richness at the wetland survey stations $(\mathrm{P} \leq 0.001)$, and the average number of species/station increased from 12.6 in 1993 to 20.7 in 1998 . These differences, however, were not constant across the groups (Figure 2). Birds in three groups increased significantly in richness including obligate wetland species, 0.5 to 7.0 species/station $(\mathrm{P} \leq 0.001)$, facultative wetland species, 1.5 to 2.0 species/station $(\mathrm{P}=$ 0.011), and facultative upland species, 3.5 to 4.4 species/station $(P=0.026)$. There were no significant differences between years for overall richness or number of species/station for total or grouped birds at the control stations.
Small increases in numbers of stations/species, a proxy for abundance, were observed in all five groups (Table 3), but significant differences were only evident in the obligate wetland group $(\mathrm{P}<0.001)$. This group increased from 0.5 to 8.0 stations/species. Regionally rare Pied-billed Grebe, American Wigeon, and Northern Shoveler had particularly high relative increases in observations between years (Table 3). The provincially rare Yellow Rail was counted at one station during the 1998 survey, but individuals were heard calling in at least two other locations within the marsh during Twenty-one species had significant differences $(\mathrm{P}=0.039$ to $\mathrm{P}<0.001)$ in station counts between 1993 and 1998, most of these as increases. Twelve species (57\%) were obligate wetland, two were facultative wetland, four were facultative, and three were facultative upland species. All obligate wetland species had positive changes between years. Those species with losses included Wilson's Warbler (facultative wetland) $(\mathrm{P}=0.002)$, Alder Flycatcher (facultative) $(\mathrm{P}=0.012)$, Ruby-crowned Kinglet (facultative) $(\mathrm{P}=0.008)$, and Mourning Warbler (facultative) $(\mathrm{P}=$ 0.039). Red-winged Blackbirds (facultative wetland) were recorded in 23 wetland stations and one control station in 1998; there were only two station observa-

TABLE 2. Summary of bird species richness by bird group at site and survey stations with percentages (in brackets) before and after wetland construction. Comparisons with total possible species in region and possible breeders in region at the bottom. Obligate Wetland (found greater than $99 \%$ in wetlands), Facultative Wetland (57-99\%, generally found in or near wetlands), Facultative (34-56\%, occurs frequently in wetlands, but wetlands are not essential), Facultative Upland (1-33\%, occasional or no use of wetlands), and Upland (found greater than $99 \%$ in uplands).

\begin{tabular}{|c|c|c|c|c|c|c|c|c|c|c|c|c|}
\hline \multirow{3}{*}{$\begin{array}{l}\text { Bird } \\
\text { Group } \\
\text { Obligate Wetland }\end{array}$} & \multirow{2}{*}{\multicolumn{2}{|c|}{$\begin{array}{c}\text { Possible } \\
\text { in Region }\end{array}$}} & \multirow{2}{*}{\multicolumn{2}{|c|}{$\begin{array}{l}\text { Possible } \\
\text { Breeding }\end{array}$}} & \multicolumn{4}{|c|}{ Before (1993) } & \multicolumn{4}{|c|}{ After (1998) } \\
\hline & & & & & \multicolumn{2}{|c|}{ Site } & \multicolumn{2}{|c|}{ Survey } & \multicolumn{2}{|c|}{ Site } & \multicolumn{2}{|c|}{ Survey } \\
\hline & 72 & (32) & 40 & (26) & 5 & (7) & 3 & (5) & 34 & (31) & 26 & (30) \\
\hline Facultative Wetland & 16 & (7) & 11 & (7) & 8 & (11) & 8 & (14) & 10 & (9) & 8 & (9) \\
\hline Facultative & 30 & (14) & 26 & (17) & 16 & (22) & 14 & (25) & 20 & (18) & 19 & (22) \\
\hline Facultative Upland & 33 & (15) & 26 & (17) & 16 & (22) & 14 & (25) & 20 & (18) & 15 & (17) \\
\hline Upland & 71 & (32) & 53 & (34) & 27 & (38) & 17 & (30) & 25 & (23) & 19 & (22) \\
\hline Total & 222 & $(100)$ & 156 & $(100)$ & 72 & (100) & 56 & (100) & 109 & $(100)$ & 87 & $(100)$ \\
\hline \multicolumn{5}{|c|}{$\%$ of Total Possible Species in the Region } & & $(32)$ & & $(25)$ & & (49) & & (39) \\
\hline \multicolumn{5}{|c|}{$\%$ of Possible Breeding Species in the Region } & & (46) & & (36) & & (70) & & (56) \\
\hline
\end{tabular}


TABLE 3. Bird species observed at the site and within survey stations before and after construction of Hilliardton Marsh. Stations column lists the number of stations in which a species was observed, which is a proxy for abundance. Asterisk denotes species observed within and outside of survey stations. See text for explanation of bird groups.

\begin{tabular}{|c|c|c|c|c|c|c|c|}
\hline \multicolumn{2}{|c|}{ Bird Species } & \multirow{2}{*}{$\begin{array}{l}\text { Abun/ } \\
\text { Status }\end{array}$} & \multirow{2}{*}{$\begin{array}{l}\text { Bird } \\
\text { Group }\end{array}$} & \multicolumn{2}{|c|}{ Before } & \multicolumn{2}{|c|}{ After } \\
\hline Common Name & Scientific Name & & & Site & Stations & Site & Stations \\
\hline Canada Goose & Branta canadensis & $\mathrm{CM}$ & \multirow{33}{*}{ 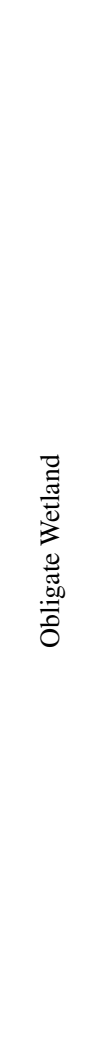 } & & & $*$ & 3 \\
\hline Wood Duck & Aix sponsa & $\mathrm{CB}$ & & & & $*$ & 6 \\
\hline American Wigeon & Anas americana & $\mathrm{CB}$ & & & & $*$ & 11 \\
\hline American Black Duck & Anas rubripes & $\mathrm{CB}$ & & & & $*$ & 1 \\
\hline Mallard Duck & Anas platyrhynchos & $\mathrm{CB}$ & & $*$ & & $*$ & 16 \\
\hline Blue-winged Teal & Anas discors & $\mathrm{C}$ & & & & $*$ & 14 \\
\hline Northern Shoveler & Anas clypeata & UB & & & & $*$ & 10 \\
\hline Northern Pintail & Anas acuta & $\mathrm{CM}$ & & & & $*$ & \\
\hline Green-winged Teal & Anas crecca & $\mathrm{CB}$ & & & & $*$ & 5 \\
\hline Ring-necked Duck & Aythya collaris & $\mathrm{CB}$ & & & & $*$ & 3 \\
\hline Common Goldeneye & Bucephala clangula & $\mathrm{CB}$ & & & & $*$ & 8 \\
\hline Hooded Merganser & Lophodytes cucullatus & $\mathrm{CB}$ & & & & $*$ & 1 \\
\hline Common Merganser & Mergus merganser & $\mathrm{CB}$ & & & & $*$ & 1 \\
\hline Pied-billed Grebe & Podilymbus podiceps & $\mathrm{CB}$ & & & & $*$ & 20 \\
\hline Horned Grebe & Podiceps auritus & $\mathrm{RM}$ & & & & $*$ & 2 \\
\hline Double-crested Commorant & Phalacrocorax auritus & $\mathrm{RM}$ & & & & $*$ & \\
\hline American Bittern & Botaurus lentiginosus & $\mathrm{CB}$ & & & & $*$ & 12 \\
\hline Great Blue Heron & Ardea herodias & $\mathrm{CB}$ & & & & $*$ & 1 \\
\hline Yellow Rail & Coturnicops noveboracensis & $\mathrm{RB}$ & & & & $*$ & 1 \\
\hline Virginia Rail & Rallus limicola & $\mathrm{RB}$ & & & & $*$ & 3 \\
\hline Sora & Porzana carolina & $\mathrm{CB}$ & & & & $*$ & 19 \\
\hline American Coot & Fulica americana & $\mathrm{CB}$ & & & & $*$ & 12 \\
\hline Sandhill Crane & Grus canadensis & $\mathrm{RB}$ & & & & $*$ & \\
\hline Lesser Yellowlegs & Tringa flavipes & $\mathrm{CM}$ & & & & $*$ & \\
\hline Spotted Sandpiper & Actitis macularius & $\mathrm{CB}$ & & & & $*$ & 3 \\
\hline Wilson's Snipe & Gallinago delicata & $\mathrm{CB}$ & & $*$ & 2 & $*$ & 26 \\
\hline American Woodcock & Scolopax minor & $\mathrm{CB}$ & & & & $*$ & \\
\hline Ring-billed Gull & Larus delawarensis & $\mathrm{CB}$ & & & & $*$ & 1 \\
\hline Black Tern & Chlidonias niger & $\mathrm{RB}$ & & & & $*$ & 3 \\
\hline Belted Kingfisher & Ceryle alcyon & $\mathrm{CB}$ & & $*$ & & $*$ & \\
\hline Marsh Wren & Cistothorus palustris & $\mathrm{RB}$ & & & & $*$ & \\
\hline Northern Waterthrush & Seiurus noveboracensis & UB & & $*$ & 3 & $*$ & 8 \\
\hline Swamp Sparrow & Melospiza georgiana & $\mathrm{CB}$ & & $*$ & 9 & $*$ & 20 \\
\hline \multicolumn{4}{|c|}{ Total in Group I; Brackets - total stations per species for group } & 5 & $3(14)$ & 34 & $26(210)$ \\
\hline \multicolumn{2}{|c|}{ Bird Species } & \multirow{2}{*}{$\begin{array}{l}\text { Abun/ } \\
\text { Status }\end{array}$} & \multirow{2}{*}{$\begin{array}{c}\text { Bird } \\
\text { Group }\end{array}$} & \multicolumn{2}{|c|}{ Before } & \multicolumn{2}{|c|}{ After } \\
\hline Common Name & Scientific Name & & & Site & Stations & Site & Stations \\
\hline Upland Sandpiper & Bartramia longicauda & $\mathrm{RB}$ & \multirow{12}{*}{ 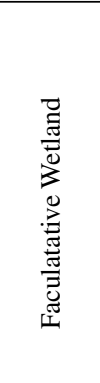 } & * & & & \\
\hline Northern Harrier & Circus cyaneus & $\mathrm{CB}$ & & $*$ & 1 & $*$ & 1 \\
\hline Great Gray Owl & Strix nebulosa & $\mathrm{RB}$ & & * & 1 & & \\
\hline Yellow-bellied Flycatcher & Empidonax flaviventris & $\mathrm{CB}$ & & $*$ & 4 & $*$ & 4 \\
\hline Winter Wren & Troglodytes troglodytes & UB & & $*$ & 2 & $*$ & 1 \\
\hline Northern Parula Warbler & Parula americana & $\mathrm{R}$ & & & & $*$ & \\
\hline Palm Warbler & Dendroica palmarum & $\mathrm{CM}$ & & & & $*$ & \\
\hline Common Yellowthroat & Geothlypis trichas & $\mathrm{CB}$ & & $*$ & 19 & $*$ & 22 \\
\hline Wilson's Warbler & Wilsonia pusilla & $\mathrm{CM}$ & & $*$ & 11 & $*$ & 1 \\
\hline Le Conte's Sparrow & Ammodramus leconteii & RB & & $*$ & 4 & $*$ & 4 \\
\hline Red-winged Blackbird & Agelaius phoeniceus & $\mathrm{CB}$ & & $*$ & 2 & $*$ & 24 \\
\hline Brewer's Blackbird & Euphagus cyanocephalus & $\mathrm{CB}$ & & & & $*$ & 1 \\
\hline \multicolumn{4}{|c|}{ Total in Group II; Brackets - total stations per species for group } & 9 & $8(44)$ & 10 & $8(58)$ \\
\hline
\end{tabular}

tions in 1993 (Table 3). Presence of the regionally rare LeConte's Sparrow remained constant at four stations between 1993 and 1998.

\section{Habitat Change and Bird Groups}

Overall numbers of species/station increased between years in similar magnitude at stations with 
TABLE 3. continued.

\begin{tabular}{|c|c|c|c|c|c|c|c|}
\hline \multicolumn{2}{|c|}{ Bird Species } & \multirow{2}{*}{$\begin{array}{l}\text { Abun/ } \\
\text { Status }\end{array}$} & \multirow{2}{*}{$\begin{array}{c}\text { Bird } \\
\text { Group }\end{array}$} & \multicolumn{2}{|c|}{ Before } & \multicolumn{2}{|c|}{ After } \\
\hline Common Name & Scientific Name & & & Site & Stations & Site & Stations \\
\hline Short-eared Owl & Asio flammeus & $\mathrm{CB}$ & \multirow{22}{*}{ 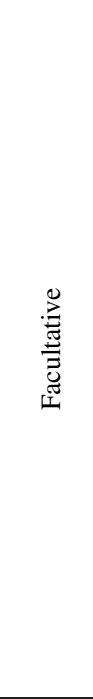 } & $*$ & & & \\
\hline Ruby-throated hummingbird & Archilochus colubris & $\mathrm{CB}$ & & $*$ & 1 & $*$ & \\
\hline Alder Flycatcher & Empidonax alnorum & $\mathrm{CB}$ & & $*$ & 19 & $*$ & 10 \\
\hline Gray Jay & Perisoreus canadensis & $\mathrm{CR}$ & & $*$ & 5 & $*$ & 1 \\
\hline Common Raven & Corvus corax & CR & & $*$ & & $*$ & 4 \\
\hline Tree Swallow & Tachycineta bicolor & $\mathrm{CB}$ & & & & $*$ & 12 \\
\hline Cliff Swallow & Petrochilidon pyrrhonota & $\mathrm{CB}$ & & & & $*$ & 1 \\
\hline Boreal Chickadee & Poecile hudsonica & RW & & & & $*$ & 2 \\
\hline Ruby-crowned Kinglet & Regulus calendula & $\mathrm{CB}$ & & $*$ & 12 & $*$ & 4 \\
\hline Veery & Catharus fuscescens & $\mathrm{CB}$ & & $*$ & 13 & $*$ & 17 \\
\hline Swainson's Thrush & Catharus ustulatus & $\mathrm{CB}$ & & $*$ & 5 & $*$ & 3 \\
\hline Hermit Thrush & Catharus guttatus & $\mathrm{CB}$ & & $*$ & 4 & $*$ & 4 \\
\hline Gray Catbird & Dumetella carolinensis & UB & & & & $*$ & 2 \\
\hline Nashville Warbler & Vermivora ruficapilla & $\mathrm{CB}$ & & $*$ & 18 & $*$ & 15 \\
\hline Yellow Warbler & Dendroica petechia & $\mathrm{CB}$ & & $*$ & 4 & $*$ & 7 \\
\hline Black-throated Blue Warbler & Dendroica caerulescens & $\mathrm{RB}$ & & & & $*$ & 1 \\
\hline Yellow-rumped Warbler & Dendroica coronata & $\mathrm{CB}$ & & $*$ & 6 & $*$ & 2 \\
\hline Connecticut Warbler & Oporornis agilis & $\mathrm{RB}$ & & $*$ & & & \\
\hline Mourning Warbler & Oporornis philadelphia & $\mathrm{CB}$ & & $*$ & 15 & $*$ & 7 \\
\hline Song Sparrow & Melospiza melodia & $\mathrm{CB}$ & & $*$ & 14 & $*$ & 18 \\
\hline Lincoln's Sparrow & Melospiza lincolnii & $\mathrm{CB}$ & & $*$ & 5 & $*$ & 5 \\
\hline Bobolink & Dolichonyx oryzivorus & $\mathrm{CB}$ & & $*$ & 10 & $*$ & 6 \\
\hline \multicolumn{4}{|c|}{ Total in Group III; Brackets - total stations per species for group } & 17 & $14(131)$ & 20 & $19(121)$ \\
\hline \multicolumn{2}{|c|}{ Bird Species } & \multirow{2}{*}{$\begin{array}{l}\text { Abun/ } \\
\text { Status }\end{array}$} & \multirow{2}{*}{$\begin{array}{c}\text { Bird } \\
\text { Group }\end{array}$} & \multicolumn{2}{|c|}{ Before } & \multicolumn{2}{|c|}{ After } \\
\hline Common Name & Scientific Name & & & Site & Stations & Site & Stations \\
\hline Peregrine Falcon & Falco peregrinus & $\mathrm{RB}$ & \multirow{21}{*}{ 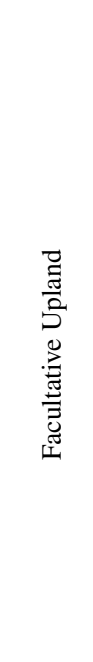 } & & & $*$ & \\
\hline Killdeer & Charadrius vociferus & $\mathrm{CB}$ & & $*$ & & $*$ & 1 \\
\hline Northern Flicker & Colaptes auratus & CB & & $*$ & 8 & $*$ & 5 \\
\hline Pileated Woodpecker & Dryocopus pileatus & $\mathrm{CR}$ & & $*$ & & $*$ & 4 \\
\hline Least Flycatcher & Empidonax minimus & CB & & $*$ & 14 & $*$ & 11 \\
\hline Eastern Kingbird & Empidonax tyrannus & $\mathrm{CB}$ & & $*$ & 1 & $*$ & 10 \\
\hline Warbling Vireo & Vireo gilvus & $\mathrm{R}$ & & & & $*$ & 3 \\
\hline American Crow & Corvus brachyrhynchos & $\mathrm{CR}$ & & $*$ & 2 & $*$ & 10 \\
\hline Barn Swallow & Hirundo rustica & $\mathrm{CB}$ & & $*$ & 1 & $*$ & 2 \\
\hline Wood Thrush & Hylocichla mustelina & $\mathrm{RB}$ & & $*$ & 1 & & \\
\hline American Robin & Turdus migratorius & $\mathrm{CB}$ & & $*$ & 19 & $*$ & 25 \\
\hline Magnolia Warbler & Dendroica magnolia & $\mathrm{CB}$ & & $*$ & 4 & $*$ & 1 \\
\hline Black-throated Green Warbler & Dendroica virens & $\mathrm{RB}$ & & & & $*$ & \\
\hline Black-and-white Warbler & Mniotilta varia & $\mathrm{CB}$ & & $*$ & 11 & $*$ & 6 \\
\hline Cedar Waxwing & Bombycilla cedrorum & $\mathrm{CB}$ & & $*$ & 1 & $*$ & \\
\hline Savannah Sparrow & Passerculus sandwichensis & $\mathrm{CB}$ & & $*$ & 14 & $*$ & 14 \\
\hline White-throated Sparrow & Zonotrichia albicollis & $\mathrm{CB}$ & & $*$ & 23 & $*$ & 18 \\
\hline Common Grackle & Quiscalus quiscula & $\mathrm{CB}$ & & $*$ & 3 & $*$ & 22 \\
\hline Baltimore Oriole & Icterus galbula & UB & & & & $*$ & 2 \\
\hline Purple Finch & Carpodacus purpureus & $\mathrm{CB}$ & & $*$ & 1 & $*$ & \\
\hline White-winged Crossbill & Loxia leucoptera & UW & & & & $*$ & \\
\hline \multicolumn{4}{|c|}{ Total in Group IV; Brackets - total stations per species for group } & 16 & $14(103)$ & 20 & $15(134)$ \\
\hline
\end{tabular}

moderate habitat change (12.5 to 21.9) and high habitat change (12.3 to 23.5$)$, but the results were only significant for the former $(\mathrm{P} \leq 0.001)$. Stations with no habitat change had 13.3 and 14.0 species/ station for each year. The high variability in the high habitat change data suggests the sample size of four was too small for significant results $(\mathrm{P}=0.068)$. By bird group, the distribution of species was somewhat more even and less variable in stations with moderate habitat change than in the other groups. However, the results were not significant (Figure 3).

\section{Rare Species}

Twenty-seven rare species were observed on site during the 1998 survey, more than double the 11 rare species observed in 1993 (Table 4). The most notable new rare species were the nationally threatened Pere- 
TABLE 3. continued.

\begin{tabular}{|c|c|c|c|c|c|c|c|}
\hline \multicolumn{2}{|c|}{ Bird Species } & \multirow{2}{*}{$\begin{array}{l}\text { Abun/ } \\
\text { Status }\end{array}$} & \multirow{2}{*}{$\begin{array}{c}\text { Bird } \\
\text { Group }\end{array}$} & \multicolumn{2}{|c|}{ Before } & \multicolumn{2}{|c|}{ After } \\
\hline Common Name & Scientific Name & & & Site & Stations & Site & Stations \\
\hline Ruffed Grouse & Bonasa umbellus & $\mathrm{CB}$ & \multirow{34}{*}{$\frac{\vec{J}}{\frac{\vec{J}}{\sigma}}$} & $*$ & & $*$ & 1 \\
\hline Broad-winged Hawk & Buteo platypterus & $\mathrm{V}$ & & $*$ & & $*$ & \\
\hline American Kestrel & Falco sparverius & $\mathrm{CB}$ & & $*$ & & $*$ & 3 \\
\hline Merlin & Falco columbarius & $\mathrm{CB}$ & & & & $*$ & 1 \\
\hline Mourning Dove & Zenaida Macroura & CR & & & & $*$ & \\
\hline Black-billed Cuckoo & Coccyzus erythropthalmus & $\mathrm{RB}$ & & & & $*$ & \\
\hline Great Horned Owl & Bubo virginianus & CR & & $*$ & & & \\
\hline Yellow-bellied Sapsucker & Sphyrapicus varius & $\mathrm{CB}$ & & $*$ & & & \\
\hline Downy Woodpecker & Picoides pubescens & $\mathrm{CR}$ & & $*$ & 3 & $*$ & 7 \\
\hline Hairy Woodpecker & Picoides villosus & CR & & $*$ & 1 & $*$ & 2 \\
\hline Eastern Wood Pewee & Contopus virens & UB & & $*$ & & & \\
\hline Blue-headed Vireo & Vireo solitarius & $\mathrm{RB}$ & & $*$ & 2 & & \\
\hline Philadelphia Vireo & Vireo philadelphicus & $\mathrm{CB}$ & & $*$ & 16 & $*$ & 20 \\
\hline Red-eyed Vireo & Vireo olivaceus & $\mathrm{CB}$ & & $*$ & 2 & $*$ & 4 \\
\hline Blue Jay & Cyanocitta cristata & $\mathrm{CR}$ & & $*$ & & $*$ & 3 \\
\hline Horned Lark & Eremophila alpestris & $\mathrm{CM}$ & & $*$ & 1 & $*$ & 2 \\
\hline Black-capped Chickadee & Poecile atricapillus & $\mathrm{CR}$ & & $*$ & 6 & $*$ & 3 \\
\hline Red-breasted Nuthatch & Sitta canadensis & $\mathrm{CR}$ & & $*$ & 1 & $*$ & \\
\hline Brown Thrasher & Toxostoma rufum & UB & & & & $*$ & 1 \\
\hline European Starling & Sturnus vulgaris & $\mathrm{CB}$ & & $*$ & 3 & $*$ & 4 \\
\hline Tennessee Warbler & Vermivora peregrina & $\mathrm{CB}$ & & $*$ & 4 & $*$ & 2 \\
\hline Chestnut-sided Warbler & Dendroica pensylvanica & $\mathrm{CB}$ & & $*$ & 11 & $*$ & 13 \\
\hline Cape May Warbler & Dendroica tigrina & UB & & & & & \\
\hline American Redstart & Setophaga ruticilla & $\mathrm{CB}$ & & $*$ & 16 & $*$ & 13 \\
\hline Ovenbird & Seiurus aurocapillus & $\mathrm{CB}$ & & $*$ & 11 & $*$ & 7 \\
\hline Chipping Sparrow & Spizella passerina & $\mathrm{CB}$ & & $*$ & 1 & $*$ & \\
\hline White-crowned Sparrow & Zonotrichia leucophrys & $\mathrm{CM}$ & & $*$ & & $*$ & \\
\hline Northern Cardinal & Cardinalis cardinalis & $\mathrm{V}$ & & & & & \\
\hline Rose-breasted Grosbeak & Pheucticus ludovicianus & $\mathrm{CB}$ & & $*$ & 1 & & \\
\hline Eastern Meadowlark & Sturnella magna & VM & & $*$ & & $*$ & 1 \\
\hline Pine Siskin & Carduelis pinus & $\mathrm{CR}$ & & $*$ & & $*$ & 1 \\
\hline American Goldfinch & Carduelis tristis & $\mathrm{CR}$ & & $*$ & 5 & $*$ & 9 \\
\hline Evening Grosbeak & Coccothraustes vespertinus & $\mathrm{CR}$ & & & & & \\
\hline House Sparrow & Passer domesticus & $\mathrm{CR}$ & & $*$ & 1 & & \\
\hline \multicolumn{4}{|c|}{ Total Group V; Brackets - total stations per species for group } & 27 & $17(85)$ & 25 & $19(97)$ \\
\hline
\end{tabular}

Abundance and status codes: $\mathrm{CB}$ - common breeder, $\mathrm{RM}$ - rare migrant, $\mathrm{CM}$ - common migrant, UB - uncommon breeder, $\mathrm{C}$ - common, $\mathrm{R}$ - rare, $\mathrm{RB}$ - rare breeder, $\mathrm{RW}$ - rare in winter, VB - very rare breeder, VM - very rare migrant, UW uncommon in winter, $\mathrm{V}$ - very rare, $\mathrm{CR}$ - common resident.

grine Falcon and four provincially significant species, including Horned Grebe, American Coot, Yellow Rail, and Black Tern. Most of the rare species observed in 1998 had some degree of wetland dependency, with 14 as obligate wetland and four as facultative wetland. In contrast, only two of the 11 rare species observed in 1993 were provincially significant: Short-eared and Great Gray Owls. Five rare species surveyed in 1993 were not observed during the post-constructions surveys and included Short-eared Owl, Upland Sandpiper, Connecticut Warbler,Wood Thrush, and Great Gray Owl (Table 4).

\section{Discussion}

\section{Habitat Change and the Bird Community}

Habitat heterogeneity can be an important element in attracting a wide variety of bird species, especially in wetlands (Creighton et al. 1997). Wetland complexes of varying water depths and flooding duration often lead to the most comprehensive array of habitat types for birds (Murkin et al. 1997). Habitat change at Hilliardton Marsh was not only dramatic but resulted in an overall increase in habitat types. In 1998, 54\% of Hilliardton Marsh was marsh habitat one to five years old. Increased vegetation diversity, percent cover, and structure attract a greater diversity of birds compared to less vegetated marshes (Whitman 1976; Kantrud and Stewart 1984; Delphey and Dinsmore 1993; Weller 1994; VanRees-Siewert and Dinsmore 1996). Many edge habitats were created and these are prime habitat for many bird species (Cyr et al.1995). Where water meets land, i.e., riparian areas, insectivorous bird abundance is often the greatest (Iwata et al. 2003). Survey stations with moderate habitat change tended to have the greatest diversity of habitats, many with hemi-marsh vegetation development, and in turn had significant increases in total species richness. 
TABLE. 4. Rare birds by status and bird group at Hilliardton Marsh Provincial Wildlife Area before (1993) and after wetland construction (1998). Rarity determined by Temiskaming Field Naturalists (1994*) for upland and wetland birds, Ontario Ministry of Natural Resources (1994) for wetland birds, and Environment Canada (2004*) for threatened birds. See text for explanation of bird groups.

\begin{tabular}{|c|c|c|c|c|}
\hline Status & Bird Group & Species & Before & After \\
\hline Threatened & Facultative Upland & Peregrine Falcon & & $*$ \\
\hline $\begin{array}{l}\text { Provincially } \\
\text { Significant }\end{array}$ & $\begin{array}{l}\text { Obligate Wetland } \\
\text { Obligate Wetland } \\
\text { Obligate Wetland } \\
\text { Obligate Wetland } \\
\text { Facultative Wetland } \\
\text { Facultative }\end{array}$ & $\begin{array}{l}\text { Horned Grebe } \\
\text { Yellow Rail } \\
\text { American Coot } \\
\text { Black Tern } \\
\text { Great Gray Owl } \\
\text { Short-eared Owl }\end{array}$ & * & $\begin{array}{l}* \\
* \\
* \\
*\end{array}$ \\
\hline $\begin{array}{l}\text { Regionally } \\
\text { Significant }\end{array}$ & $\begin{array}{l}\text { Obligate Wetland } \\
\text { Obligate Wetland } \\
\text { Obligate Wetland } \\
\text { Obligate Wetland } \\
\text { Obligate Wetland } \\
\text { Obligate Wetland } \\
\text { Obligate Wetland } \\
\text { Obligate Wetland } \\
\text { Facultative Wetland } \\
\text { Facultative Wetland } \\
\text { Facultative } \\
\text { Facultative Upland } \\
\text { Facultative Upland } \\
\text { Upland } \\
\text { Upland }\end{array}$ & $\begin{array}{l}\text { American Wigeon } \\
\text { Northern Shoveler } \\
\text { Pied-billed Grebe } \\
\text { Double-crested Cormorant } \\
\text { Virginia Rail } \\
\text { Sora } \\
\text { Sandhill Crane } \\
\text { Marsh Wren } \\
\text { Upland Sandpiper } \\
\text { Le Conte's Sparrow } \\
\text { Connecticut Warbler } \\
\text { Warbling Vireo } \\
\text { Wood Thrush } \\
\text { Horned Lark } \\
\text { Eastern Meadowlark }\end{array}$ & $\begin{array}{l}* \\
* \\
* \\
* \\
* \\
* \\
*\end{array}$ & $\begin{array}{l}* \\
* \\
* \\
* \\
* \\
* \\
* \\
* \\
* \\
* \\
* \\
* \\
*\end{array}$ \\
\hline $\begin{array}{l}\text { Locally } \\
\text { Significant }\end{array}$ & $\begin{array}{l}\text { Obligate Wetland } \\
\text { Obligate Wetland } \\
\text { Facultative Wetland } \\
\text { Facultative } \\
\text { Facultative Upland } \\
\text { Upland }\end{array}$ & $\begin{array}{l}\text { Canada Goose } \\
\text { Northern Waterthrush } \\
\text { Winter Wren } \\
\text { Gray Catbird } \\
\text { Baltimore Oriole } \\
\text { Brown Thrasher }\end{array}$ & * & $\begin{array}{l} \\
* \\
* \\
* \\
* \\
*\end{array}$ \\
\hline
\end{tabular}

Constructed wetlands may evolve towards the ecological characteristics of natural wetlands within a few years (Sistani et al. 1999), and wetland age has been positively correlated with increases in native wetland plant species diversity and richness (Reinartz and Warne 1993). Compared to younger wetlands with less vegetation development, wetlands four years of age have been found to have higher wetland avian species richness (VanRees-Siewert and Dinsmore 1996; Wan et al. 2001). This corresponds to the average wetland cell age at Hilliardton Marsh of 3.5 years with a range of 1-5 years in 1998. Smaller areas with homogeneous stands of Cattail (Typha latifolia) (with some open water) are critical for attracting species such as Marsh Wren (Verner and Engelson 1970), and this rare regional breeder was first seen at Hilliardton Marsh in 1998. However, vegetation communities are dynamic and this study captured only the initial effects of wetland vegetation development on the bird community. In new impoundments, plant succession tends to advance to stable, rooted aquatic plants and rapidly increasing invertebrate populations have been found to stabilize within two years. Thus, the initial conditions that proved favourable for many species of waterbirds diminishes (Whitman 1976). Unless the vegetation communities are maintained for a diversity of habitat types by managers, the bird community at Hilliardton Marsh will continue to change, especially for obligate wetland species. For example, increased growth of Cattail between 1998 and 1999 was documented and would attract certain birds; e.g., Marsh Wren and Red-Winged Blackbird, but displace others that favour more open habitats, e.g., diving ducks. Wooded wetland habitats such as treed swamps are used by some waterfowl for nesting or cover (Cadman et al. 1987; Merendino et al. 1995), including Common Goldeneye, Ring-necked Duck, Hooded Merganser, and Wood Duck (Table 3). The treed swamps at Hilliardton Marsh are temporary habitat, as the dominant tree is Trembling Aspen, a non-wetland species. Although these trees were alive one year after the Hilliardton Marsh was constructed, the extended flooding would eventually kill the trees leaving a dead-tree swamp (c.f. Ontario Ministry of Natural Resources 1994). That habitat structure will eventually collapse with high water levels and inevitably become marsh or shallow water habitat that is less attractive to birds with wooded-wetland affinities. 


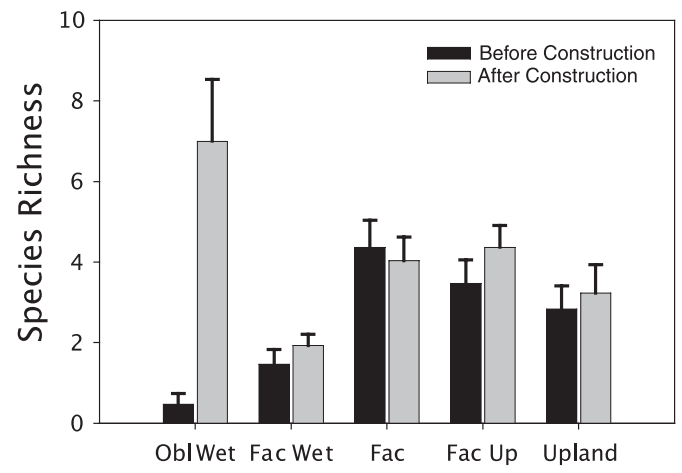

Bird Groups

FIGURE 2. Species richness by bird group before and after wetland construction with $95 \%$ confidence interval error bars. $\mathrm{OB} 1 \mathrm{Wet}=$ Obligate Wetland, Fac Wet $=$ Facultative Wetland, Fac $=$ Facultative, Fac Up = Facultative Upland. See text for explanation of bird groups.

\section{Rare Habitat, Rare Species}

Marsh habitat is the rarest wetland habitat in northern Ontario (National Wetlands Working Group 1988; Riley 1988). Bird species from the southern boreal region of Ontario and Quebec that inhabit open water marsh (and swamp) habitats are limited by the occurrence of these habitats (Cadman et al. 1987; Gauthier and Aubry 1996). Similar studies on the effects of restored or created wetlands have shown significant increases in numbers of obligate wetland species, numbers of individuals, and rare obligate wetland species (Dick 1993; Hickman 1994; Pollard et al. 2000). Of the rare birds observed at Hilliardton Marsh, of particular importance are those that are provincially significant. American Coot, Black Tern, and Yellow Rail are rare breeders in northern Ontario (Cadman et al. 1987). Amerian Coot and Black Tern have declined in numbers and distribution over the past two decades (Cadman et al. 1987; Austen et al. 1994), and Yellow Rails are among the most reclusive birds in Ontario (Bart et al. 1984).

It is also significant that observations and abundances of many species of rare birds did not change between years. Open, riparian habitat for the facultative wetland LeConte's Sparrow (Cadman et al. 1987) lost during wetland construction was recreated during the same process in different locations. Open, prairietype habitat that is suitable for Horned Lark and Eastern Meadowlark (Cadman et al. 1987) was maintained.

Additionally, some new and rare birds, mostly at the local level, were observed from the facultative, facultative upland, and upland groups during 1998. These included Warbling Vireo, Gray Catbird, Baltimore Oriole, and Brown Thrasher (Table 3). Some rare species such as Upland Sandpiper and Connecticut Warb-

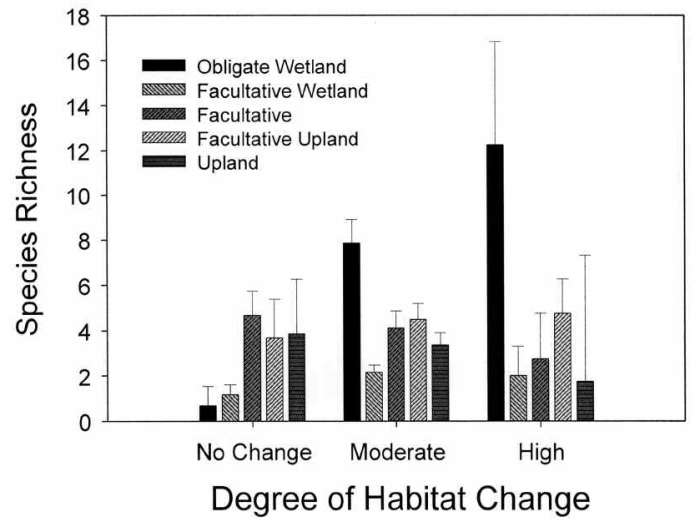

FIGURE 3. Degree of habitat change after wetland construction and bird species richness by bird groups with 95\% confidence interval error bars. See text for explanation of bird groups.

ler observed in 1993 were not observed in any of the post-construction surveys, and this could be attributable to natural variation within the bird population (Holyoak and Baillie 1996). We were reasonably confident that varying weather conditions; e.g., drought, was not a factor affecting bird species abundance between years. Long-distance migrants such as Ovenbirds and Red-eyed Vireos are often more susceptible to drought (Blake et. al. 1992); numbers recorded in the control stations were stable between years and precipitation records for the study period indicated no anomalies.

Continued monitoring of the bird community at Hilliardton Marsh would be necessary to determine long-term trends at the species level, especially for rare species. Additionally, new wetland projects run the risk of eradication of existing important habitat or have negative impacts on rare species (Keddy and Wisheu 1989; Hickman 1994). Maintaining habitat amenable to all rare species should be a high management priority at Hilliardton Marsh.

\section{Conclusions}

This study provides an initial view of the response of the bird community during the breeding season to wetland construction in a region where there have been few studies on birds. Bird diversity increased significantly in response to wetland construction, especially wetland birds. Constructed wetlands are not always successful in augmenting the bird community and the intended use and consequences must be carefully planned (Zhijun et al. 2004). The original aim of creating Hilliardton Marsh was to provide waterfowl habitat, and this and related work (Locky 1999) have shown this aim to be met. However, wetland construction has also attracted a range of non-target, nonwaterfowl wetland species, while maintaining the 
natural diversity of the original upland bird community, including rare species. A number of new wetland rare species were also attracted. This construction has been particularly favorable because the marsh habitat that was introduced is rare in the region. Therefore, the type of habitat being created is an important consideration when designing wetland construction projects and is also a consideration for continued management of constructed wetland systems. Like all wetlands, constructed wetlands are dynamic systems and long-term management and surveys would be required to ensure that the enduring potential of providing wetland bird habitat is maintained.

\section{Acknowledgments}

Alison Buchanan and Bruce Murphy assisted in the field and Doug Brook and Peter Davis provided helpful discussion. Valuable comments provided by A. J. Erskine, S. R. Wilkinson, M. N. Thormann, S. J. Hannon, S. E. Bayley, and an anonymous reviewer substantially improved this manuscript, and were greatly appreciated. This study was supported by the Northeast Science and Technology Unit of the Ministry of Natural Resources, Ducks Unlimited Canada, and the Natural Sciences and Engineering Research Council of Canada.

Documents Cited (marked * in text)

Canadian Wildlife Service. 1997. Forest Bird Monitoring Program - Site Set-Up and Bird Survey Instructions. Canadian Wildlife Service, Guelph, Ontario.

Ducks Unlimited Canada. 1986. Surveying site plan for Hilliardton Marsh. Ducks Unlimited, Timmins, Ontario.

Environment Canada. Species at risk. 2004. Homepage: http://www.speciesatrisk.gc.ca/defaulte.cfm Accessed 2004.

Huizer, R., and B. Henshaw. 1997. Comparative breeding bird survey Hilliardton Marsh Provincial Wildlife Area. Jacques Whitford Environmental Limited, Ottawa, Ontario.

Temiskaming Field Naturalists. 1994. Birds of the Little Clay Belt. Ontario Ministry of Natural Resources/Temiskaming Field-Naturalists Club, Swastika, Ontario.

\section{Literature Cited}

American Ornithologist' Union. 1998. The AOU Checklist of North American Birds: Seventh edition. American Ornithologists' Union, Washington, D.C.

American Ornithologist' Union. 2000. The forty-second supplement to the American Ornithologists' Union checklist of North American birds. Auk 117: 847-858.

American Ornithologist' Union. 2002. The forty-third supplement to the American Ornithologists' Union checklist of North American birds. Auk 119: 897-906.

American Ornithologist' Union. 2003. The forty-fourth supplement to the American Ornithologists' Union checklist of North American birds. Auk 120: 923-931.

American Ornithologist' Union. 2004. The forty-fifth supplement to the American Ornithologists' Union checklist of North American birds. Auk 121: 985-995.

Austen, M. J. W., M. D. Cadman, and R. D. James. 1994. Ontario birds at risk: status and conservation needs. Federation of Ontario Naturalists and Long Point Bird Observatory, Don Mills, Ontario.
Bart, J., R. A. Stehn, J. A. Herrick, T. A. Heaslip, T. A. Bookhout, and J. R. Stenzel. 1984. Survey methods for breeding yellow rails. Journal of Wildlife Management 48: 1382-1386.

Bell, B. D., C. K. Catchpole, K. J. Corbett, and R J. Hornby. 1973. The relationship between census results and breeding populations of some marshland passerines. Bird Study 20: 127-140.

Bibby, C. J., N. D. Burgess, and D. A. Hill. 1993. Bird Census Techniques. Third edition. Academic Press Limited San Diego, California.

Blake, J. G., G. J. Niemi, and J. M. Hanowski. 1992. Drought and annual variation in bird populations. Pages 419-430 in Ecology and conservation of neotropical migrant landbirds. Edited by J. M. Hagen III and D. W. Johnson. Smithsonian Institutional Press, Washington D.C.

Brooks, R. P., and M. J. Croonquist. 1990. Wetland, habitat, and trophic response guilds for wildlife species in Pennsylvania. Journal of the Pennsylvania Academy of Science 64: 93-102.

Cadman, M. D., P. F. J. Eagles, and F. M. Helleiner. Editors. 1987. Atlas of Breeding Birds of Ontario. University of Waterloo Press, Waterloo, Ontario.

Conover, W. J. 1980. Practical Nonparametric Statistics. Second edition. John Wiley and Sons Inc., Toronto, Ontario.

Creighton, J. H., R. D. Sayler, J. E. Tabor, and M. J. Monda. 1997. Effects of wetland excavation on avian communities in eastern Washington. Wetlands 17: 216227.

Croonquist, M. J., and R. P. Brooks. 1991. Use of avian and mammalian guilds as indicators of impacts in riparianwetland areas. Environmental Management 15: 701-714.

Cyr, A., D. Lepage, and K. Freemark. 1995. Evaluating point count efficiency relative to territory mapping in cropland birds. Pages 63-67 in Monitoring bird populations by point counts. Edited by C. J. Ralph, J. R. Sauer, and S. Droege. General Technical Report PSW-GTR-149. United States Department of Agriculture, Forest Service, Albany, California.

Davies, J. C., B. G. Warner, P. Adams, H. Wilson, and P. Davis. 1996. The Eastern Habitat Joint Venture (EHJV) Project Hilliardton Wetland Creation Project: Pre-Project Inventory. Northeast Science and Technology, Timmins, Ontario.

Debinsky, D. M., and P. S. Humphrey. 1997. An integrated approach to biological diversity assessment. Natural Areas Journal 17: 355-365.

Delphey, P. J., and J. J. Dinsmore. 1993. Breeding bird communities of recently restored and natural prairie potholes. Wetlands 13: 200-206.

Dick, T. M. 1993. Restored wetlands as management tools for wetland-dependent birds. Pennsylvania Birds 7: 4-6.

Dredge, L. A., and W. R. Cowan. 1989. Quaternary geology of the southwestern Canadian Shield. Pages 214-249 in Quaternary geology of Canada and Greenland. Edited by R. J. Fulton. Geological Survey of Canada, Ottawa, Ontario.

Elphick, C. S. 1997. Correcting avian richness estimates for unequal sample effort in atlas studies. Ibis 139: 189-190.

Erskine, A. J. 1977. Birds in boreal Canada. Report Number 41. Canadian Wildlife Service, Ottawa, Ontario.

Freemark, K., and C. Rogers. 1995. Modification of point counts for surveying cropland birds. Pages 69-73 in Monitoring bird populations by point counts. Edited by C. J. 
Ralph, J. R. Sauer, and S. Droege. General Technical Report PSW-GTR-149. United States Department of Agriculture, Forest Service, Albany, California.

Gauthier, J., and Y. Aubry. 1996. The Breeding Birds of Quebec: Atlas of the breeding birds of Southern Quebec. Province of Quebec Society for the Protection of Birds, Canadian Wildlife Service, Environment Canada, Quebec Region, Montreal, Quebec.

Gilbert, J. M. 1997. Dynamics of vegetation development in a newly created habitat wetland in Northeastern Ontario. M.E.S. Geography thesis, University of Waterloo, Waterloo, Ontario.

Hickman, S. 1994. Improvement of habitat quality for nesting and migrating birds at the Des Plaines River wetlands demonstration project. Ecological Engineering 3: 485494.

Holyoak, M., and S. R. Baillie. 1996. Factors influencing detection of density dependence in British birds. 2. Longevity and population variability. Oikos 108: 54-63.

Hurlbert, S. H. 1984. Pseudoreplication in ecological experiments. Ecological Monographs 5: 187-211.

Hutto, R. L., S. M. Pletschet, and P. Hendricks. 1986. A fixed-radius point count method for nonbreeding and breeding season use. Auk 103: 593-602.

Iwata, T., S. Nakano, and M. Murakami. 2003. Stream meanders increase insectivorous bird abundance in riparian deciduous forests. Ecography 26: 325-337.

Kantrud, H. A., and R. E. Stewart. 1984. Ecological distribution and crude density of breeding birds on prairie wetlands. Journal of Wildlife Management 48: 426-437.

Keddy, P. A., and I. C. Wisheu. 1989. Why ignorance isn't bliss: Biological considerations in wetlands management. Pages 81-86 in Wetlands: Inertia or Momentum. Edited by M. J. Bardecki and N. Patterson. Federation of Ontario Naturalists, Don Mills, Ontario.

Leschisin, D. A., G. L. William, and M. W. Weller. 1992. Factors affecting waterfowl use of constructed wetlands in northeastern Minnesota. Wetlands 12: 178-183.

Locky, D. A. 1999. Effects of wetland restoration on breeding birds in boreal northeastern Ontario. M.Sc. Biology thesis. Department of Biology, University of Waterloo, Waterloo, Ontario.

Merendino, M. T., G. B. McCulloch, and N. R. North. 1995. Wetland availability and use by breeding waterfowl in southern Ontario. Journal of Wildlife Management 59: 527-532.

Murkin, H. R., E. J. Murkin, and J. P. Ball. 1997. Avian habitat selection and prairie wetland dynamics: a 10-year experiment. Ecological Applications 7: 1144-1159.

National Wetlands Working Group. 1988. Wetlands of Canada. Ecological Land Classification Series, Number 24. Sustainable Development Branch, Environment Canada, Ottawa, Ontario; and Polyscience Publications Inc., Montreal, Quebec.

National Wetlands Working Group. 1997. The Canadian Wetland Classification System. Second edition. Edited by B. G. Warner and C. D. A. Rubec. Wetlands Research Centre, Waterloo, Ontario.

Ontario Ministry of Natural Resources. 1994. Ontario Wetland Evaluation System, Northern Manual. Third edition. NEST Technical Manual TM-001. Peterborough, Ontario.
Pollard, J. B., C. M. Bauchman, and K. McAloney. 2000. The effect of Atlantic dykeland wetland restoration on breeding wetland-obligate avian species. Pages 231-241 in Limnology and aquatic birds, monitoring, modelling and management conference proceeding. Edited by F. A. Comin, J. A. Herrera-Silverira, and J. Ramirez-Ramirez. Universidad Autonoma de Yucatan, Meridan, Yucatan, Mexico.

Ralph, C. J., J. R. Sauer, and S. Droege. Editors. 1995. Monitoring bird populations by point counts. General Technical Report PSW-GTR-149. United States Department of Agriculture, Forest Service, Albany, California.

Reinartz, J. A., and E. L. Warne. 1993. Development of vegetation in small created wetlands in southeastern Wisconsin. Wetlands 13: 153-164.

Riley, J. L. 1988. Southern Ontario bogs and fens off the Canadian Shield. Pages 355-368 in Wetlands: Inertia or Momentum. Edited by M. J. Bardecki and N. Patterson. Federation of Ontario Naturalists, Don Mills, Ontario.

Ritchie, G. 1988. Somewhere way up here: a perspective on northern Ontario wetlands. Pages 213-219 in Wetlands: Inertia or Momentum. Edited by M. J. Bardecki and N. Patterson. Federation of Ontario Naturalists, Don Mills, Ontario.

SPSS Inc. 2002. SPSS for Windows version 11.5.1. SPSS Inc.: Chicago, Illinois.

Simberloff, D., and T. Dayan. 1991. The guild concept and the structure of ecological communities. Annual Review of Ecology and Systematics 22: 115-143.

Sistani, K. R., M. A. Mays, and R. W. Taylor. 1999. Development of natural conditions in constructed wetlands: biological and chemical changes. Ecological Engineering 12: 125-131.

Smith, W. J. 1957. Birds of the Clay Belt of northern Ontario and Quebec. Canadian Field-Naturalist 71: 163181.

VanRees-Siewert, K. L., and J. J. Dinsmore. 1996. Influence of wetland age on bird use of restored wetlands in Iowa. Wetlands 16: 577-582.

Verner, J., and G. H. Engelson. 1970. Territories, multiple nesting-building, and polygyny in the Long-billed Marsh Wren. Auk 87: 557-567.

Wan, S. W., P. Qin, W. Li, and X. P. Liu. 2001. Wetland creation for rare waterfowl conservation: A project designed according to the principles of ecological succession. Ecological Engineering 18: 115-120.

Weller, M. W. 1994. Freshwater marshes: ecology and management. Third edition. University of Minnesota Press, Minneapolis, Minnesota.

Whitman, W. R. 1976. Impoundments for waterfowl. Occasional Paper Number 22. Canadian Wildlife Service, Ottawa, Ontario.

Zhijun, M., B. Li, K. Jing, S. Tang, and J. Chen. 2004. Are artificial wetlands good alternatives to natural wetlands for waterbirds? - A case study on Chongming Island, China. Biodiversity and Conservation 13: 333350 .

Received 15 March 2004

Accepted 7 February 2005 